\title{
Physiological Basis of The Correction of Postural Disorders by Regular Ordered Muscular Activity
}

\section{Bases fisiológicas de la corrección de los trastornos posturales mediante actividad muscular ordenada regularmente}

\author{
Yanina Vasilievna Shimanovskaya* \\ Federal State Budgetary Educational Institution of Higher Education "Russian State Social \\ University" (RSSU), Moscow, Russia. \\ ORCID: https://orcid.org/0000-0003-0282-1323
}

Svetlana Vasilievna Shmeleva

K.G. Razumovsky Moscow State University of technologies and management (the First

Cossack University), Moscow, Russia.

ORCID: https://orcid.org/0000-0003-0390-194X

Antonina Nikolaevna Vakulenko

K.G. Razumovsky Moscow State University of technologies and management (the First

Cossack University), Moscow, Russia.

ORCID: https://orcid.org/0000-0003-4878-9752

\section{Konstantin Leonidovich Pisarevsky}

K.G. Razumovsky Moscow State University of technologies and management (the First

Cossack University), Moscow, Russia.

ORCID: https://orcid.org/0000-0002-8403-8051

Anton Anatolyevich Karpinsky

Federal State Institution of Education «Russian University of Transport», Moscow, Russia. ORCID: https://orcid.org/0000-0002-2144-8248

\author{
Alexander Alexandrovich Seliverstov \\ K.G. Razumovsky Moscow State University of technologies and management (the First \\ Cossack University), Moscow, Russia. \\ ORCID: https://orcid.org/0000-0002-7847-4711
}

Received 02-12-20 Revised 03-13-20 Accepted 07-13-20 On line 08-29-20

*Correspondence

Email: shimanovskaya.y.v@mail.ru
Cite as: 


\section{Summary}

Posture deformation occurs under the influence of factors that violate the vertical position of the spine. When the load on the spine is redistributed, the position of the body is adjusted by selective training of the muscles of the trunk and changing the position of the pelvis in the frontal plane. Exercises for impaired posture should be aimed primarily at preventing progression and correcting curvature and twisting of the vertebrae. It is important not only the correction of curvature, but also the stabilization of the spine in a corrected position. Saving the achieved results contributes to the formation of a new static-dynamic stereotype of the spine. This is possible by deliberately influencing the upper and lower in relation to the main curvature of the links of the musculoskeletal system and muscle tone-regulating groups involved in posture formation.

Keywords: Physiology; Posture; Physical Activity; Muscle Activity; Spine.

\section{Resumen}

La deformación de la postura ocurre bajo la influencia de factores que violan la posición vertical de la columna vertebral. Cuando la carga en la columna se redistribuye, la posición del cuerpo se ajusta mediante el entrenamiento selectivo de los músculos del tronco y cambiando la posición de la pelvis en el plano frontal. Los ejercicios para una postura alterada deben estar dirigidos principalmente a prevenir la progresión y corregir la curvatura y la torsión de las vértebras. Es importante no solo la corrección de la curvatura, sino también la estabilización de la columna vertebral en una posición corregida. Guardar los resultados obtenidos contribuye a la formación de un nuevo estereotipo estático-dinámico de la columna vertebral. Esto es posible al influir deliberadamente en la parte superior e inferior en relación con la curvatura principal de los enlaces del sistema musculoesquelético y los grupos de regulación del tono muscular involucrados en la formación de la postura.

Palabras clave: Fisiología; Postura; Actividad física; Actividad muscular; Columna vertebral.

\section{Introduction}

Violations of posture are formed under the influence of various reasons. The initial elimination of these causes is the prevention of posture disorders (Mal, Zavalishina, 2019). It should be aimed at the systematic development of the muscles of the body, improving the cardiovascular and respiratory systems. Of great importance in this matter are the means of physical fitness (Epifanov, Epifanov, 2008).

Recently, simulators have been introduced into preventive physical education everywhere, which allow targeted action on the body. This is important because it becomes possible to dose the load by force, pace and amplitude of movement. The exercises used on the simulators are able to act on strictly separate muscle groups and joints. In addition, the implementation of such exercises provides dosing of energy costs of the body (Simonenko, Medvedev, Tolmachev, 2011).

The development of modern health science and its practical application is due to the development of the sports and health industry, the progress of sports and accessories and pharmacological technologies (Medvedev, Skoryatina, 2013).

Objective: to consider the physiological basis of the correction of posture disorders.

Recently, physical culture has become very popular, it includes general developmental and special exercises for the main muscle groups. Exercises are performed with free weights, but 
in terms of effectiveness they are inferior to exercises performed on special simulators that provide movements in various modes of muscle work, with different amplitudes and differentiation of the load value (Medvedev, 2017).

Competent physical education classes are the best means of healing and preventing postural disorders (Karpov et al., 2019a). However, illiterate physical exercises on the spine of a person with a violation of posture, often leads to increased pressure on the concave side of the spine and exacerbates the situation (Karpov et al., 2019b).

In building a training program and choosing a method for posture disorders, everything should obey strict logic - ensuring the optimum physical condition, rigorous testing, choice of exercise strategy, compliance with exercise methods (Medvedev, 2019).

Correction of muscle disorders in case of posture disorders is based on a decrease in tone and stretching of shortened muscles that impede the correction of curvature, as well as strengthening of muscles that ensure the preservation of correction results (Penkova et al., 2018; Zavalishina, Medvedev, 2016).

Muscular activity is a natural means of physiological stimulation, which improves adaptive mechanisms at various levels of life. The work of muscles is determined by a combination of changes in their traction and length (Medvedev, Skoryatina, Zavalishina, 2016).

Strength exercises are used for health-improving purposes and help to strengthen the micropump functions of skeletal muscles, which, when contracted, squeeze blood into the vessels, and when relaxed, they attract it. The detected injection function of skeletal muscles during their rhythmic stretching with various weights is very effective during recovery (Skoryatina, Medvedev, Zavalishina, 2017).

In case of violations of posture, exercises with gymnastic sticks, dumbbells, balls provide local and dosed power tension, muscle stretching, coordination of movements. Exercises with objects have a stronger effect on the body than similar exercises without objects, this happens due to the weight of the used object, the presence of lever when the movement of a body segment, an increase in inertial forces arising from swing movements (Zavalishina, Medvedev, 2017).

Special shells, apparatuses and simulators used in case of violation of posture provide a greater effect due to the exact dosage of the load, an increase in the tensile effect or stress intensity. Mechanical work for differentiated or local effects on a given muscle group is modeled on weight training machines. By changing the load, amplitude, pace of movement and the position of the student on the simulator, a different effect is achieved (Shmeleva et al., 2018).

A positive factor for performing weight training exercises is the ability to dose the load with a fairly high degree of accuracy. This provides opportunities for the selection of individual training loads, taking into account functional and age characteristics (Morozova et al., 2018).

The degree of impact of physical activity on the human body with a violation of posture depends on certain characteristics such as the intensity and duration of the exercise, the number of repetitions, the number and quality of rest, the position of the person exercising on the simulator (Shmeleva et al., 2018).

A positive factor for performing weight training exercises is the ability to dose the load with a fairly high degree of accuracy. This provides opportunities for the selection of individual training loads, taking into account functional and age characteristics (Morozova et al., 2018). 
The degree of impact of physical activity on the human body with a violation of posture depends on its chosen characteristics: the intensity and duration of the exercise, the number of repetitions, rest pauses and their nature, as well as the type of exercises used. A change in these characteristics causes certain biochemical changes in the body, and the combined effect leads to a significant reorganization of the metabolism, which is reflected in an improvement in functional fitness (Tkacheva, Zavalishina, 2019).

Active physical activity performed in the optimal volume and intensity throughout a person's life, normalizes posture, improves the efficiency and reliability of the cardiovascular system and the whole organism. A stepwise increase in muscle loads during their systematic use has a significant advantage over uniform and significantly increases the degree of adaptation to it (Neymatov, Sabinin, 2012).

\section{Method}

The method of repeated exercises is widely used in the correction of posture disorders. This method is very effective, since a large amount of work causes significant shifts in the metabolism, creates opportunities for increased plastic metabolism, leading to functional hypertrophy of the muscles with an increase in their strength, which allows you to enhance the effect of exercises.

Special physical exercises constitute the main group of means for the formation and consolidation of correct posture (Karpov et al., 2019c). Corrective exercises, against which the curvature arc is corrected, include the following:

1. Asymmetric exercises, which are based on the principle of spinal correction. They provide a soft effect on its curvature, moderate stretching of muscles and ligaments on a concave arch of curvature and differentiated strengthening of weakened muscles on the convex side.

2. Symmetric exercises, which are based on the minimum biomechanical effect of special exercises on existing curvatures. When performing these exercises, it is not necessary to take into account the complex biomechanical conditions of the deformed system, which minimizes the risk of their erroneous use. They have a different effect on the symmetrically located muscles of the trunk, which, as a result of spinal deformity, are in a physiologically unbalanced state.

3. Detorsion exercises aimed at correcting existing deformities and preventing possible spinal disorders. When performing these exercises, there is a soft rotation of the vertebral bodies in the direction opposite to torsion, correction of the curvature of the spine with alignment of the pelvic line, stretching of the contracted and strengthening of the stretched muscles in the lumbar and thoracic spine.

\section{Results}

Symmetric and asymmetric exercises are used for violations of posture mainly to affect the spine in the frontal plane. To influence the deformation in the horizontal plane, special corrective exercises of a derotational nature are used (Karpov et al., 2019d).

Unloading the spine is a prerequisite for general and local effects on it. The most common unloading position is horizontal. In the supine position, muscle tension is removed and the spine can be given the appropriate position. In this case, the center of gravity changes, and the body acquires the largest support area, ensuring stable equilibrium. Unloading the spine not only allows you to more effectively affect the deformation zone, but also improves blood circulation and lymph circulation in the surrounding muscles and ligaments.

A variety of physical exercises predetermines a different approach to the issue of breathing control during the performance of various exercises. It is known that when performing 
exercises between breathing and movement, a certain relationship is established. Moreover, it is considered true if the respiratory act is gently "inscribed" with the process of performing movements. Used breathing exercises lead to the normalization and improvement of the mechanism of breathing and the coordination of breathing and movements, strengthening the respiratory muscles, improving the mobility of the chest and diaphragm, and preventing and correcting chest deformities (Mikhailova et al., 2019).

A variety of physical exercises predetermines a different approach to the issue of breathing control during the performance of various exercises. It is known that when performing exercises between breathing and movement, a certain relationship is established. Moreover, it is considered true if the respiratory act is gently "inscribed" with the process of performing movements. Used breathing exercises lead to the normalization and improvement of the mechanism of breathing and the coordination of breathing and movements, strengthening the respiratory muscles, improving the mobility of the chest and diaphragm, and preventing and correcting chest deformities (Mikhailova et al., 2019).

The state of fitness that occurs during the regular performance of exercises is associated with the adaptation of the body to training loads. Adaptation in case of impaired posture is faster if the load remains standard for some time, in which case the body is easier to adapt to it. From this point of view, in case of posture disturbances, it is advisable to choose a certain unchanging set of exercises and repeat it for a sufficiently long time, changing only the load and the number of approaches. But using the same complex will lead to the fact that its implementation will become familiar and will cause small adaptation shifts. Therefore, with violations of posture, it is recommended to periodically change the complex used (once every 6-8 weeks). The frequency of physical exercises for violations of posture depends on a number of factors, for example, on the initial physical fitness of the students.

\section{Conclusion}

The development of posture disorders is the result of pathological factors that violate the normal condition of the spine. This can be counteracted by redistributing the loads on the spine. This provides posture correction due to selective training of the muscles of the body, changes in the position of the pelvis in the frontal plane. Redistribution of loads is always accompanied by a positive change in the configuration of the spine. Therefore, physical exercises for violations of posture should be aimed at preventing their progression correction and twisting of the vertebrae. Correction of deformity without measures to ensure stabilization of the spine is ineffective. The effect achieved during posture correction can be preserved by forming the patient's correct staticdynamic stereotype and optimized position of his body. This is done through targeted action on the entire spine and the location of the pelvis by optimizing the tone of the muscle groups involved in the formation of posture.

\section{References}

Epifanov, V.A., Epifanov, A.V. (2008). Reconstructive treatment for diseases and injuries of the spine. Moscow: MEDpress-inform.

Karpov, V.Yu., Medvedev, I.N., Komarov, M.N., Lapina, N.M., Sharagin, V.I. (2019b). Physical Rehabilitation of Adolescents with Bronchial Asthma. Indian Journal of Public Health Research \& Development, 10(8), 1910-1914.

Karpov, V.Yu., Medvedev, I.N., Romanova, A.V., Usov, S.S., Kozyakov, R.V. (2019a). Functional Disorders in the Respiratory System in Adolescents with Bronchial Asthma. Indian Journal of Public Health Research \& Development, 10(8), 1904-1909.

Karpov, V.Yu., Zavalishina, S.Yu., Romanova, A.V., Komarov, M.N., Sharagin, V.I. (2019d). Congenital Heart Defects in Children and the Main Approaches to Rehabilitation After 
their Surgical Treatment. Indian Journal of Public Health Research \& Development, 10(10), 1303-1307.

Karpov, V.Yu., Zavalishina, S.Yu., Romanova, A.V., Voevodina, T.M. (2019c). Physiological Mechanisms of Rehabilitation in Vegetative Vascular Dystonia. Indian Journal of Public Health Research \& Development, 10(10), 1261-1265.

Mal, G.S., Zavalishina, S.Yu. (2019). Functional Platelet Activity During Ontogeny in Rats. Indian Journal of Public Health Research \& Development, 10(8), 1915-1919.

Medvedev, I.N. (2017). The Impact of Durable and Regular Training in Handto-hand Fighting Section on Aggregative Platelet Activity of Persons at the First Mature Age. Annual Research \& Review in Biology, 15(2), 1-6.

Medvedev, I.N. (2019). Physiological response of the rheological parameters of erythrocytes to regular physical exertion in individuals of the first mature age who are at risk of hemodynamic and metabolic disturbances. International Journal of Pharmaceutical Research, 11(4), 257-262.

Medvedev, I.N., Skoryatina, I.A. (2013). Fluvastatin effects on blood cell aggregation in patients with arterial hypertension and dyslipidemia. Cardiovascular Therapy and Prevention, 12(2), 18-24.

Medvedev, I.N., Skoryatina, I.A., Zavalishina, S.Yu. (2016). Aggregation ability of the main blood cells in arterial hypertension and dyslipidemia patients on rosuvastatin and nondrug treatments. Cardiovascular therapy and prevention, 15(5), 4-10.

Mikhailova, I.V., Shmeleva, S.V., Karpov, V.Yu., Sharagin, V.I., Shimanovskaya, Ya.V., Petrova, M.A., Alifirov, A.I., Eremin, M.V. (2019). Correction of motor disturbances in children with cerebral paralysis and moderate mental retardation. Bali Medical Journal, $8(2), 379-383$.

Morozova, E.V., Shmeleva, S.V., Rysakova, O.G., Bakulina, E.D., Zavalishina, S.Yu. (2018). Psychological Rehabilitation of Disabled People Due to Diseases of the Musculoskeletal System and Connective Tissue. Prensa Med Argent, 104(2).

Neymatov, E.M., Sabinin, S.L. (2012). Handbook of an osteopath. Fundamentals of the biomechanics of body movement. Moscow: Medical Information Agency.

Penkova, I.V, Karpova, N.V., Shmeleva, S.V., Kartashev, V.P. (2018). Health disorders prevention in preschoolers by means of physical education: historical aspect. The European proceedings of social and behavioural sciences, 122, 1042-1047.

Shmeleva, S.V., Yunusov, F.A., Morozov, Yu.S., Seselkin, A.I., Zavalishina, S.Yu. (2018). Modern Approaches to Prevention and Correction of the Attorney Syndrome at Sportsmen. Prensa Med Argent, 104(2).

Simonenko, V.B., Medvedev, I.N., Tolmachev, V.V. (2011). Dynamics of primary hemostasis activity in patients with arterial hypertension and metabolic syndrome treated with candesartan. Klinicheskaia meditsina, 89(3), 35-38.

Skoryatina, I.A., Medvedev, I.N., Zavalishina, S.Yu. (2017). Antiplatelet control of vessels over the main blood cells in hypertensives with dyslipidemia in complex therapy. Cardiovascular therapy and prevention, 16(2), 8-14.

Tkacheva, E.S., Zavalishina, S.Yu. (2019). Functional Features of Platelet Secretion in Piglets During Early Ontogenesis. Biomedical \& Pharmacology Journal, 12(1), 485-489.

Zavalishina, S.Yu., Medvedev, I.N. (2016). Features aggregation erythrocytes and platelets in old rats experiencing regular exercise on a treadmill. Advances in gerontology, 29(3), 437441.

Zavalishina, S.Yu., Medvedev, I.N. (2017). Comparison of opportunities from two therapeutical complexes for correction of vascular hemostasis in hypertensives with metabolic syndrome. Cardiovascular therapy and prevention, 16(2), 15-21. 